\title{
A Method for Landscape-Scale Vegetation Assessment: Application to Great Basin Rangeland Ecosystems
}

\author{
Tara A. Forbis, ${ }^{1}$ Louis Provencher, ${ }^{2}$ Lee Turner, ${ }^{3}$ Gary Medlyn, ${ }^{4}$ Julie Thompson, ${ }^{5}$ and Gina Jones ${ }^{6}$
}

Authors are ${ }^{1}$ Eastern Nevada Project Ecologist, The Nature Conservancy, Ely, NV 89315; ${ }^{2}$ Nevada Director of Conservation Science, The Nature Conservancy, Ely, NV 89315; ${ }^{3}$ Ecologist, Otis Bay Ecological Consultants, Reno, NV 89523; ${ }^{4}$ Watersheds Project Manager, Ely Bureau of Land Management, Ely, NV 89501; ${ }^{5}$ Ecologist, Eastern Nevada Landscape Coalition, Ely, NV 89501; and ${ }^{6}$ Intern, Otis Bay Ecological Consultants, Reno, NV 89523.

\begin{abstract}
The growth of landscape-scale land management necessitates the development of methods for large-scale vegetation assessment. Field data collection and analysis methods used to assess ecological condition for the 47 165-h North Spring Valley watershed are presented. Vegetation cover data were collected in a stratified random design within 6 Great Basin vegetation types, and the probability of detecting change in native herbaceous cover was calculated using power analyses. Methods for using these quantitative assessment data are presented to calculate a departure index based on reference condition information from LANDFIRE (an interagency effort to map and model fire regimes and other biophysical characteristics at a mid-scale for the entire United States) Biophysical Setting models for the mountain big sagebrush (Artemisia tridentata Nutt. subsp. vaseyana [Rydb.] Beetle) vegetation type. For mountain big sagebrush in the North Spring Valley landscape, we found that the earliest successional classes were underrepresented and that mountain big sagebrush moderately invaded by conifers was more abundant than predicted by the LANDFIRE reference based on the historic range of variability. Classes that were most similar to the reference were mountain big sagebrush with the highest conifer cover and late development mountain big sagebrush with perennial grasses. Overall, results suggested that restoration or approximation of the historic fire regime is needed. This method provides a cost-effective procedure to assess important indicators, including native herbaceous cover, extent of woody encroachment, and ground cover. However, the method lacks the spatial information that would allow managers to comprehensively assess spatial patterns of vegetation condition across the mosaics that occur within each major vegetation type. The development of a method that integrates field measurements of key indicators with remotely sensed data is the next critical need for landscape-scale assessment.
\end{abstract}

\section{Resumen}

La creciente tendencia a manejar la tierra a nivel de paisaje requiere del desarrollo de métodos para evaluar la vegetación a gran escala. Se presentan los métodos de colección de datos en campo y su análisis usados para evaluar la condición ecológica de 47 165-ha de la cuenca hidrológica North Spring Valley. Se colectaron datos de cobertura vegetal dentro de seis tipos de vegetación de La Gran Cuenca, el muestro se realizó bajo un diseño aleatorio estratificado y la probabilidad de detectar cambios en la cobertura de herbáceas nativas fue calculado usando análisis de poder. Se presentan métodos para utilizar estos datos cuantitativos de evaluación para calcular un índice de variación basado en información de la condición de referencia de los modelos de Escenarios Biofísicos LANDFIRE para tipos de vegetación "Mountain big sagebrush" (Artemisia tridentata Nutt. subsp. vaseyana [Rydb.] Beetle). Para el "Mountain big sagebrush" en el paisaje del North Spring Valley encontramos que, las clases iniciales de sucesión fueron subrepresentadas y que el "Mountain big sagebrush" invadido moderadamente por coníferas fue más abundante que lo predicho por la referencia del LANDFIRE, basado en el rango histórico de variabilidad. Las clases más similares a la referencia fueron: el "Mountain big sagebrush" con la mayor cobertura de coníferas y las etapas finales de desarrollo del "Mountain big sagebrush" con zacates perennes. Los resultados globales sugieren que se necesita la restauración o la aproximación del régimen histórico de fuego. Este método provee un procedimiento efectivo en costos para evaluar indicadores importantes, incluyendo la cobertura de herbáceas nativas, la cantidad de invasión de leñosas y la cobertura de suelo. Sin embargo, el método carece de información espacial que permitiría a los manejadores evaluar ampliamente los patrones espaciales de la condición de la vegetación a través de los mosaicos que ocurren dentro de cada tipo principal de vegetación. El desarrollo de un método que integre mediciones de campo de indicadores clave mediante datos de sensores remotos es el siguiente paso crítico para la evaluación a escala de paisaje.

Key Words: landscape ecology, ecological condition, reference condition, monitoring, sagebrush semidesert, vegetation dynamics, thresholds

Research was funded in part by the Bureau of Land Management under Task Order 3, FAA030004, to the Eastern Nevada Landscape Coalition.

Mention of a proprietary product does not constitute a guarantee or warranty of the product by BLM or the authors and does not imply its approval to the exclusion of the other products that also may be suitable.

Correspondence: T. A. Forbis, The Nature Conservancy of Nevada, PO Box 150266, Ely, NV 89315. Email: tforbis@tnc.org

Manuscript received 5 April 2006; manuscript accepted 11 January 2007.

\section{INTRODUCTION}

The advent and growth of ecoregional initiatives with the goal of managing landscapes at regional scales reflects an ongoing management shift. Past management often focused on smallscale project sites and associated resource uses, such as timber yield, livestock production, or recreation. However, there is 
a shift toward ecosystem management strategies that integrate ecological processes with resource uses in management decision making (Swanson and Franklin 1992; Gram et al. 2001). The inclusion of an adaptive management cycle in this process necessitates the development of assessment and monitoring programs appropriate to large spatial and temporal scales.

Examples of landscape-scale assessment programs are most common in the wildlife literature, especially assessment for threatened, rare, and elusive species (Thompson 2004; McKelvey et al. 2005), where regulation, such as the Endangered Species Act, has created funding opportunities to track variables at regional scales. However, landscapescale assessment of major vegetation types is equally if not more important. The ecological condition, defined as the level of departure from the historic range of variability (i.e., reference condition), of landscapes must be assessed to determine appropriate land use and management plans, including suitability for wildlife and species of special concern.

Landscape-scale data on rangelands are especially sparse. A few significant analyses of ecological condition of grazing lands have been done, with notable examples from Ethiopia (Oba et al. 2000) and Australia (Bastin et al. 2002). The lack of landscape-scale data on rangelands has led to the conclusion that there is insufficient information to assess the condition of grasslands and shrublands in the United States (Heinz Center 2002). Most past rangeland assessment efforts have focused on measurement of uses, particularly livestock utilization, rather than on ecological condition or functionality (Pyke and Herrick 2004).

A landscape-scale sampling design will be useful to land managers if data can 1) efficiently capture meaningful variation over vast landscapes, 2) identify problem areas and help design restoration projects, and 3 ) be collected in a format that allows for comparison with available data on reference condition. The designation of an ecosystem or community reference condition is an essential part of any assessment protocol. We use the following definition of reference condition: the set of ecosystem characteristics, including composition, structure, and function, that would have occurred under the historic range of variability (Stephenson 1999).

Here, we provide a description of the methods used by The Nature Conservancy, the Eastern Nevada Landscape Coalition, and the Ely Field Office of the Bureau of Land Management (BLM) to assess ecological condition of current community composition and compare it to the reference condition using a LANDFIRE Biophysical Setting description for watersheds within the Eastern Nevada Landscape Restoration Project area. These methods include a quantitative, power analysis-based assessment that uses cost-effective field data to calculate a departure index (i.e., a measure of the difference between current and reference conditions) that can be used to inform management decisions and policy recommendations. We present here field data from 6 major vegetation types and a comparison of one of these types (mountain big sagebrush) with reference condition. This approach does not utilize remotely sensed data; however, we discuss the need to combine field and remotely sensed data and some possible approaches.

\section{METHODS}

The development of our assessment program and our methods were strongly influenced by Herrick et al. (2005), which provides a detailed, clear framework for establishing an assessment and/or monitoring program.

\section{Study Area}

Data were collected in the North Spring Valley within White Pine County, Nevada. White Pine County is located in the center of the Great Basin ecoregion, in the Calcareous Mountains floristic province. It consists of high-elevation north-south mountain ranges separated by relatively highelevation valleys and foothills of sagebrush semidesert. North Spring Valley is flanked by the Schell Creek Range to the west and the Antelope Range to the east, with elevations ranging from the valley floor at $2000 \mathrm{~m}$ to Becky Peak in the Schell Creek Range at $3005 \mathrm{~m}$.

Vegetation types in North Spring Valley are distributed along elevational zones. Generally, salt desert scrub communities dominated by shadscale (Atriplex confertifolia [Torr. \& Frém.] S. Wats.), alkali sacaton (Sporobolus airoides [Torr.] Torr.), and winterfat (Krashennenikovia lanata [Pursh] Guldenstaedt) types inhabit the lowest zones of lower valleys, with Wyoming sage (Artemisia tridentata Nutt. subsp. wyomingensis [Beetle and Young]) communities at slightly higher elevations. Above this zone are black sage (Artemisia nova [A. Nels.]) communities. Where volcanic soil occurs in a zone typically inhabited by black sage communities, low sage (Artemisia arbuscula Nutt.) communities occur. Above the black sage communities lies the mountain sage (Artemisia tridentata Nutt. subsp. vaseyana [Rydb.] Beetle) community, which is overlapped by pinyon-juniper woodland (Pinus monophylla Torr. \& Frém and Juniperus osteosperma [Torr.] Little) and curl-leaf mountain mahogany (Cercocarpus ledifolius Nutt. var. intermontanus N. Holmgren) zones, depending on soil type.

The BLM manages $89 \%$ of the watershed, with $2.5 \%$ being private and $7.6 \%$ at the southwest corner managed by the US Forest Service. Because the study was funded by BLM, we included only the BLM portion of the lands in our study area, which totaled 48082 ha.

\section{Reference Condition: LANDFIRE Models}

For many landscapes, it is difficult to obtain reliable information on ecological reference condition to guide restoration and management. There are many alternative ways to designate reference condition; we chose to use information from LANDFIRE because it represents the most recent, thorough attempt to define reference conditions for the Great Basin and because models and data are relevant and accessible to land managers.

LANDFIRE is a collaborative project between the wildland fire management programs of the US Department of Agriculture Forest Service, US Department of the Interior, and The Nature Conservancy. It is an effort to map and model fire regimes and other biophysical characteristics at a midscale for the entire United States. LANDFIRE products will include over 100 geospatial data layers that can be used in fire and other resource management and planning. A component of LAND- 
Table 1. Vegetation classes in the mountain big sagebrush potential vegetation type of North Spring Valley, Nevada. These vegetation classes represent successional stage, and the proportion of land area in each class is from the LANDFIRE Biophysical Setting model for Intermountain Basins Montane Sagebrush Steppe (see Methods section). Annual grass, exotic forb, seeded, and altered (i.e., burned and eroded) classes are termed "uncharacteristic" in the LANDFIRE Biophysical Setting models, so no desired proportions of these types are provided. The last column compares our field data on current condition to the expected proportions from LANDFIRE.

\begin{tabular}{|c|c|c|c|c|c|}
\hline Vegetation class & Shrub cover & Herb cover & Conifer cover & Proportion from LANDFIRE & Proportion from field data \\
\hline A: Early development & $0 \%-5 \%$ & $50 \%-80 \%$ & 0 & 20 & 0 \\
\hline \multirow{2}{*}{$\begin{array}{l}\text { B: Mid-development open- } \\
\text { shrubs }\end{array}$} & $6 \%-25 \%$ & & & 50 & 6.9 \\
\hline & & $>50 \%$ & 0 & & \\
\hline \multirow{2}{*}{$\begin{array}{l}\text { C: Late-development closed- } \\
\text { shrubs }\end{array}$} & & $<50 \%$ & & 15 & 27.7 \\
\hline & $26 \%-45+\%$ & & $<10 \%$ & & \\
\hline \multirow{2}{*}{$\begin{array}{l}\text { D: Late-development open- } \\
\text { trees }\end{array}$} & $26 \%-40 \%$ & $<30 \%$ & & 10 & 58.4 \\
\hline & & & $11 \%-25 \%$ & & \\
\hline \multirow{2}{*}{$\begin{array}{l}\text { E: Late-development closed- } \\
\text { trees }\end{array}$} & $0 \%-20 \%$ & $<20 \%$ & & 5 & 6.9 \\
\hline & & & $26 \%-80 \%$ & & \\
\hline Annual grass & $\sim 0 \%$ & $\sim 0 \%$ & $\sim 0 \%$ & 0 & 0 \\
\hline Exotic forbs & $\sim 0 \%$ & $\sim 0 \%$ & $\sim 0 \%$ & 0 & 0 \\
\hline Seeded & $\sim 0 \%$ & $\sim 0 \%$ & $\sim 0 \%$ & 0 & 0 \\
\hline Altered & $\sim 0 \%$ & $\sim 0 \%$ & $\sim 0 \%$ & 0 & 0 \\
\hline
\end{tabular}

FIRE is Fire Regime Condition Class (http://www.frcc.gov), a tool for evaluating departure of current fire and vegetation characteristics from reference conditions. LANDFIRE is sponsored by the Wildland Fire Leadership Council and is considered critical to the success of implementation of the National Fire Plan by agency leads in both the USDA Forest Service and the Department of the Interior. In our example, we use the LANDFIRE Biophysical Setting (i.e., potential vegetation type) model for Inter-Mountain Basins Montane Sagebrush Steppe, which was developed for the Great Basin Region in 2005 (http://www.landfire.gov; L. Provencher is the Great Basin Region lead for LANDFIRE).

Because LANDFIRE models describe the "presettlement" reference condition, they generally include phases within 1 state, namely, here the shrub with perennial grass state, but not different states, as would be recognized in the contemporary state-and-transition model framework (Stringham et al. 2003). The Inter-Mountain Basins Montane Sagebrush Steppe Biophysical Setting (the Biophysical Setting model that we use as a reference condition example in this study) is an exception because it includes a threshold for conifer encroachment; thus, it includes 2 states in the reference condition.

The LANDFIRE Biophysical Setting models define reference conditions as the characteristic mosaic of vegetation, including composition and structure and frequency and severity of disturbances, under the historic range of variability. The historic range of variability is defined as the conditions that are presumed to have existed prior to Euro-American settlement under current climatic conditions. Each of the LANDFIRE models addresses a Biophysical Setting unit (vegetation type) based on qualitative descriptions of the ecological systems identified in Comer et al. (2003) and defines the expected proportion of land area in each vegetation class under the historic range of variability. Information in the LANDFIRE model was based on peer-reviewed opinion arrived at through a series of expert workshops.

We obtained information on the expected proportion of land area in each of our model's vegetation classes under the historic range of variability from the LANDFIRE Biophysical Setting model for Inter-Mountain Basins Montane Sagebrush Steppe (http://www.landfire.gov). These expected proportions are shown in Table 1.

\section{Indicator Selection}

The selection of indicators is a first key step in the development of an assessment program. For the Eastern Nevada Landscape Restoration Project's assessment program, we selected 1) foliar native herbaceous cover, 2) pinyon and juniper density and age structure, and 3) ground cover as our indicators of ecological condition. The primary rationale for these selections is that native herbaceous cover is negatively correlated with the nonnative cheatgrass (Bromus tectorum L.) cover (Anderson and Inouye 2001). Additionally, the land managers were interested in obtaining inventory data on age structures of trees encroaching into shrubland sites to predict current and future management needs. Finally, ground cover is associated with soil stability and hydrologic function (Thurow 1991).

\section{Stratified Random Design}

In the past, BLM's utilization monitoring has focused on key areas, subjectively chosen to reflect "typical" conditions, generally across an allotment. However, this method does not allow for extrapolation beyond the plot area (BLM 1996), and it is not statistically representative of the larger region (Elzinga et al. 1998; Holthausen et al. 2005). For most assessment projects, sampling plots should be established in a stratified random design. Random plot location removes the observer bias that is inherent in the key areas method, and stratification can remove some of the variation due to differences in either vegetation type or soil type.

For the North Spring Valley assessment, we stratified sampling based on potential rather than current vegetation type. Using potential vegetation is particularly important when one vegetation type has replaced another because of anthropogenic effects (e.g., the displacement of shrublands by pinyon 
and juniper due to fire suppression and other causes). This allows current vegetation to be compared with potential vegetation so that departure from reference conditions can be estimated.

Potential vegetation types were mapped using the Natural Resource Conservation Service (NRCS) Order 3 soil survey. Each soil map unit from the digital soil survey map is a polygon consisting of up to 7 soil components or ecological sites (we will refer to them as ecological sites). An ecological site has abiotic characteristics (soil, topography, climate) that create the potential for a particular vegetation type to occur there (USDA NRCS 1997). The NRCS description of each soil map unit ranks the spatial extent of the ecological sites occurring within that map unit. However, the ecological sites themselves are not spatially mapped in the Order 3 soil survey digital map; rather, they have been identified to occur somewhere within their soil map unit polygon. Our sampling stratification methodology (generating random points within polygons in a Geographic Information System) requires that the strata (in this case the major vegetation types) be spatially explicit. We faced the problem of the lack of spatial information about ecological sites and so chose to stratify vegetation based on the soil map units rather than on ecological sites. We assigned the vegetation type from the dominant ecological site within each soil map unit to the entire map unit. Therefore, we lost the information about the subdominant ecological sites and made the assumption that the vegetation of the major ecological site could reasonably characterize the entire soil map unit polygon. This resulted in the translation of the soil survey map unit polygons into vegetation type polygons, which ranged in size from 3 to 7465 ha (Fig. 1).

When in the field, we rejected any sampling plot that fell in an inclusion of the soil map unit and reclassified any sampling plot whose dominant vegetation was not the one specified. This approach would not be valid for small-scale assessments, but we felt that it was valid for assessment of watersheds in our project area, which range from 3540 to 318500 ha. However, when possible, it would be preferable to stratify sampling based on ecological sites, which would be straightforward if using a finer-resolution soil survey. It is possible to use elevation models and remotely sensed data to model the occurrence of ecological sites within soil map polygons, and this is the approach that we would advocate and that we plan to use in the future.

Sampling plots were generated within each of these major vegetation type polygons in ARCView GIS 3.2 using a random point generator (http://www.jennessent.com/arcview/random points.htm; Fig. 1).

Each sampling plot included 4 parallel $50-\mathrm{m}$ transects located $10 \mathrm{~m}$ apart. We chose to use 4 transects per plot as follows. We collected pilot data in 10 plots using 5 transects per plot, which we guessed would be the highest possible number of transects needed to reliably estimate herbaceous vegetation cover per plot. Next, we compiled data subsets using data from $1,2,3,4$, and 5 transects from each plot by randomly selecting transects to avoid spatial pattern effects. From these data subsets, we created a curve for mean herbaceous cover, our indicator of most interest, for each number of transects. Precision of the estimate of herbaceous cover increased from the subsets of data using 1 transect through the subsets of data

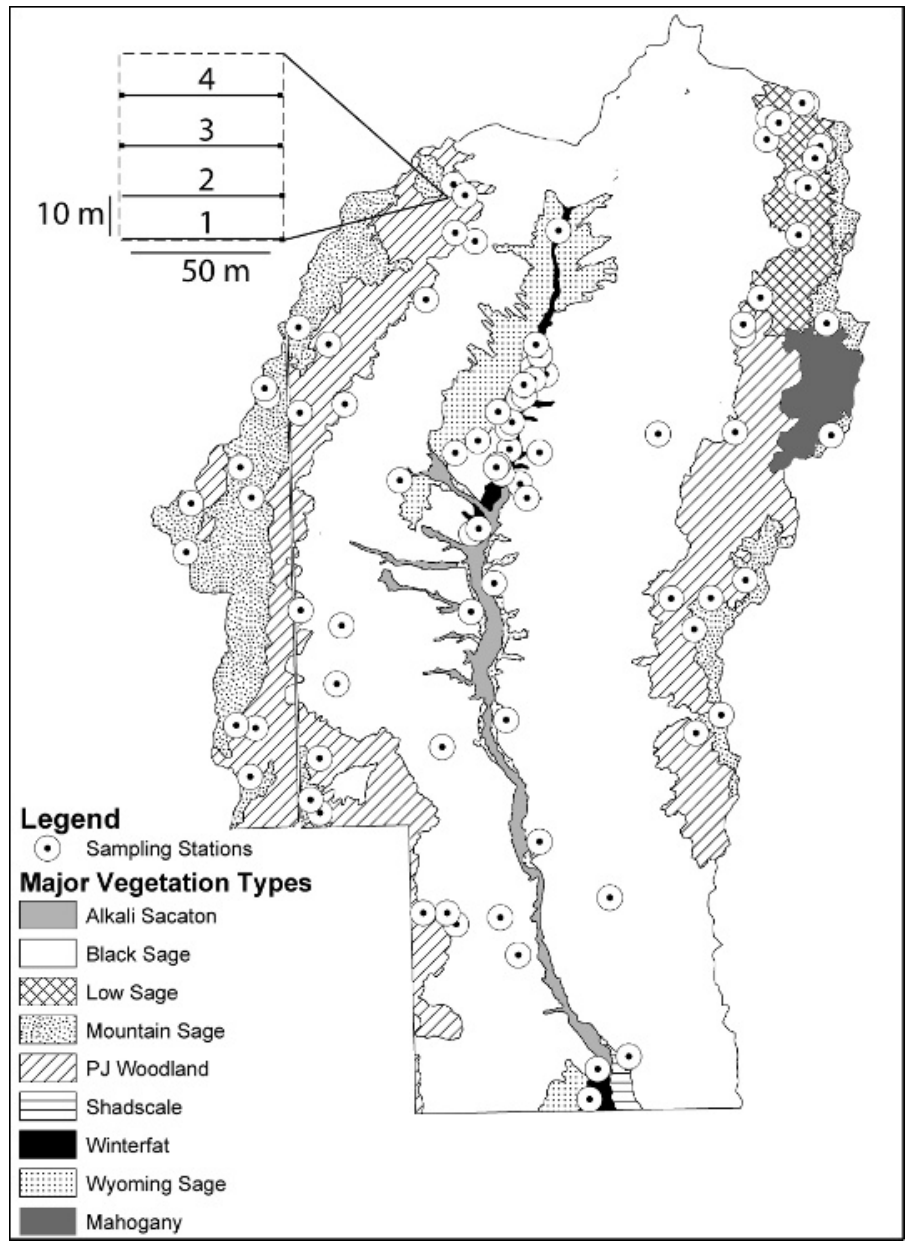

Figure 1. A map of North Spring Valley showing major vegetation type polygons and sampling plots, which were created with a stratified random design with major vegetation type as the strata. The inset shows the arrangement of 4 parallel transects within 1 sampling plot.

using 4 transects and stabilized at that point, so we chose to use 4 transects per sampling plot.

In the field, we rejected sampling plots that fell within inclusions so that we could stay within the major vegetation type. Points that fell in inappropriate locations (in/on a road, mine spoils or tailings, cliff, gravel pit, water collection device, cattle corral, power line clearing, or other human-made object) were rejected.

Sampling plots were created for the most abundant 6 of the total 9 vegetation types (Fig. 1). Shadscale, curl-leaf mountain mahogany, and alkali sacaton vegetation types were not sampled, as they made up only $0.3 \%, 1.6 \%$, and $2.1 \%$ of the watershed land area, respectively.

\section{Point-Intercept Sampling}

Point-intercept sampling was used to estimate vegetative cover of all species. Along each transect, 50 points were sampled for a total of 200 data points per sampling plot. Random numbers were generated using a stopwatch so that within each meter segment of the transect, we sampled 1 randomly located point. This removed the potential for sampling to be biased by the regular spatial patterning of shrubs and interspaces, a common 
problem in shrublands (Malkinson et al. 2003). At each point, a meter-long pin flag was lowered while the technician looked away to avoid observer bias. The overstory and understory species and the ground cover touched by the pin were recorded. All plants were recorded if the pin contacted any part of the plant. Where there was a tall overstory (i.e., conifers), a densitometer (a mirrored, leveled device that can isolate an overhead sampling point) was used. In general, vegetation sampling methods follow those for point-intercept sampling from Herrick et al. (2005). Vascular plants were identified to species, while mosses and lichens were identified only as moss or lichen. Nomenclature for vascular plants follows Cronquist et al. (1972).

To determine densities and age structures of pinyon and juniper trees, belt transect sampling was conducted along the fourth transect in each plot. The belt transect was sampled with a 2-m-wide pole that was carried $1 \mathrm{~m}$ off the ground. All seedlings and trees whose stems were within the $50 \times 2 \mathrm{~m}$ plot were counted and placed into 1 of the 4 following size classes based on stem diameter at ground level: seedlings, 1 to 4 inches, 4 to 8 inches, and 8 to 12 inches. Following the conclusion of sampling at each plot, a botanist walked throughout the plot for 10 minutes and recorded the presence of species not encountered during sampling. These species were assigned a $0.01 \%$ cover value.

\section{Power Analysis}

Along with the use of randomly located plots, power analysis is the key feature of this methodology that ensures statistical validity. Power analysis refers to the analysis of sampling data to determine the sample size necessary to detect a change in the variable being sampled (Fairweather 1991; Nickerson and Brunnell 1998). If power analysis is not performed, it is difficult to interpret a nonsignificant result (i.e., a result of no difference) because the lack of significance could be due to either a true lack of difference or the size of the data set being insufficient to detect a difference. Power analysis is also important in allowing researchers to plan sampling in a cost-effective manner. In performing power analysis, we used the following equation (from Elzinga et al. 1998, app. 7):

$$
\mathrm{n}=\left(\mathrm{Z}_{\mathrm{alpha}}\right)^{2} \times(\mathrm{s})^{2} /(\mathrm{B})^{2}
$$

where $\mathrm{n}$ is the sample size estimate, $\mathrm{Z}_{\mathrm{alpha}}$ is the standard normal coefficient corresponding to the desired confidence level, $\mathrm{s}$ is the standard deviation, and $\mathrm{B}$ is the desired precision level expressed as half the maximum acceptable confidence interval width. Using this equation, we determined the number of plots necessary to achieve $80 \%$ confidence (alpha $=0.2$ ) of detecting the true mean of native herbaceous vegetation with a confidence interval that is within $25 \%$ of the mean. Power analysis was done separately on the data for each vegetation type to determine the number of plots per vegetation type. As sampling progressed, we repeatedly made power analysis calculations on our preliminary data to help us estimate how many total plots we would need. This allowed us to estimate ahead of time the effort required to complete field sampling.

\section{Statistical Analysis of Departure Index}

Field data from North Spring Valley were summarized by sampling plot (i.e., the randomly generated points consisting of the 4 transects shown in the inset in Fig. 1). For each sampling plot, percent cover of woody plants, grasses, forbs, and invasives were calculated. Using these data, we placed each plot from the mountain big sagebrush vegetation type into one of the categories shown in Table 1.

The categories in Table 1 represent the successional classes from the LANDFIRE Biophysical Setting model for Intermountain Basins Montane Sagebrush Steppe. Class A is "Early development," the class that would be expected soon after disturbance. The dominant plant species are all herbaceous, with expected cover groups shown in Table 1 . Replacement fire with a mean fire return interval of 80 years is expected, and succession to class B would be expected after 12 years. Class B is "mid-development open-shrubs" with the expected cover classes shown in Table 1 and mountain big sagebrush cover up to $20 \%$. Initiation of conifer seedling establishment is expected, and replacement fire has a mean return interval of 40 years. Succession to class $\mathrm{C}$ would be expected after 38 years. Class $\mathrm{C}$ is "late-development closed-shrubs" with the expected cover classes shown in Table 1. The conifer cover referred to can include juniper, pinyon-juniper, ponderosa pine, or white fir. Insects and disease are expected to occur every 75 years on average and will cause thinning and a transition to class $B$. Replacement fire occurs every 50 years on average. In the absence of fire for 80 years, vegetation will transition to class D. Class D is "late-development, open-trees" with the expected cover classes shown in Table 1. Conifers, including the species listed previously for class $\mathrm{C}$, are the upper life form. Shrub cover is generally less than in class C. The mean return interval of replacement fire is 50 years. Insects and diseases can thin the sagebrush every 75 years on average, without causing a transition to other classes. Succession is from D to E after 50 years. Class E is "late-development closed-trees" with the expected cover classes shown in Table 1 . Conifers are the dominant life form. The mean interval of replacement fire is 75 years. Conifers are susceptible to insects and diseases that cause transition to class $\mathrm{D}$ every 75 years on average.

For the mountain big sagebrush type, the percent of sampling plots in each of these classes was compared to the expected percent of land area in each class from our reference condition estimates (Table 1). These 2 percentages were compared using a chi-square test to determine whether the distribution of land area/sampling plots differed between reference conditions and current conditions.

\section{RESULTS}

Numbers presented in the text and figures represent mean $\pm 95 \%$ confidence interval, a measure of error that we felt would be more meaningful to managers than standard errors or standard deviations (Steidl and Thomas 2000). Although our goal for statistical power was $80 \%$ confidence (alpha $=0.2$ ) of detecting the true mean of native herbaceous vegetation with a confidence interval that is within $25 \%$ of the mean, we felt that it was more conventional to present the results with a $95 \%$ confidence interval for easy interpretation. Ninety-five percent 


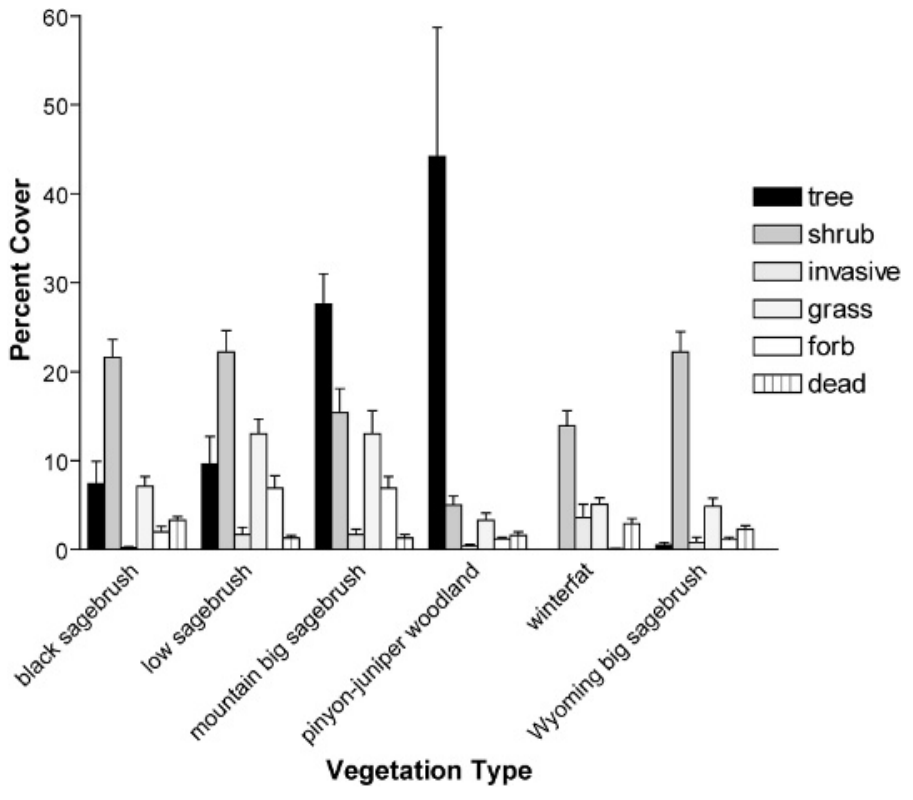

Figure 2. Percent cover of 6 plant functional groups within 6 major vegetation types from North Spring Valley field data.

confidence intervals are a standard way to present data on differences among groups and visually represent statistically significant differences at the alpha $=0.05$ level. Our goal of $80 \%$ confidence of detecting the true mean was based on feasibility of cost-effectively collecting data and on direction from BLM.

\section{General Vegetation and Ground Cover Results for All Vegetation Types}

The numbers of plots required per vegetation type, based on the power analysis described previously, were as follows: 13 in mountain big sagebrush, 14 in Wyoming big sagebrush, 16 in black sagebrush, 8 in winterfat, 11 in low sagebrush, and 15 in pinyon juniper woodland, for a total of 77 plots.

Tree cover was highest in the pinyon-juniper woodland vegetation type (Fig. 2) with most consisting of pinyon $(32.1 \pm 52.5 \%)$ and juniper $(9.6 \pm 25 \%)$. There was no tree cover in the winterfat vegetation type (Fig. 2). Shrub cover was similar in black, low, and Wyoming sagebrush types $(21.6 \pm 2.0 \%, 22.2 \pm 2.4 \%$, and $22.2 \pm 2.3 \%$, respectively, Fig. 2). Grass cover (which included only native species) was highest in the low and mountain big sagebrush vegetation types $(14.7 \pm 8.1 \%$ and $13.0 \pm 2.6 \%$, respectively; Fig. 2$)$ and lowest in the pinyon-juniper woodland vegetation type $(3.3 \pm 0.8 \%$; Fig. 2$)$. Forb cover was highest in mountain $(6.8 \pm 6.2 \%$; Fig. 2$)$ and low (5.7 $\pm 1.4 \%$; Fig. 2$)$ sagebrush vegetation types and lowest in winterfat type $(0.1 \pm 0.05 \%$; Fig. 2).

The only invasive weeds encountered during sampling were cheatgrass and halogeton (Halogeton glomeratus [Bieb.] C.A. Mey.). The highest cover of invasives occurred in winterfat type (Fig. 2), where halogeton had $3.6 \pm 27.0 \%$ cover. Black sagebrush had the lowest cover of invasive species $(0.3 \pm$ $0.25 \%$; Fig. 2).

Pinyon-juniper woodland had the highest density of trees, with most of the trees in the seedling $(242.8 \pm 117.6$ stems per

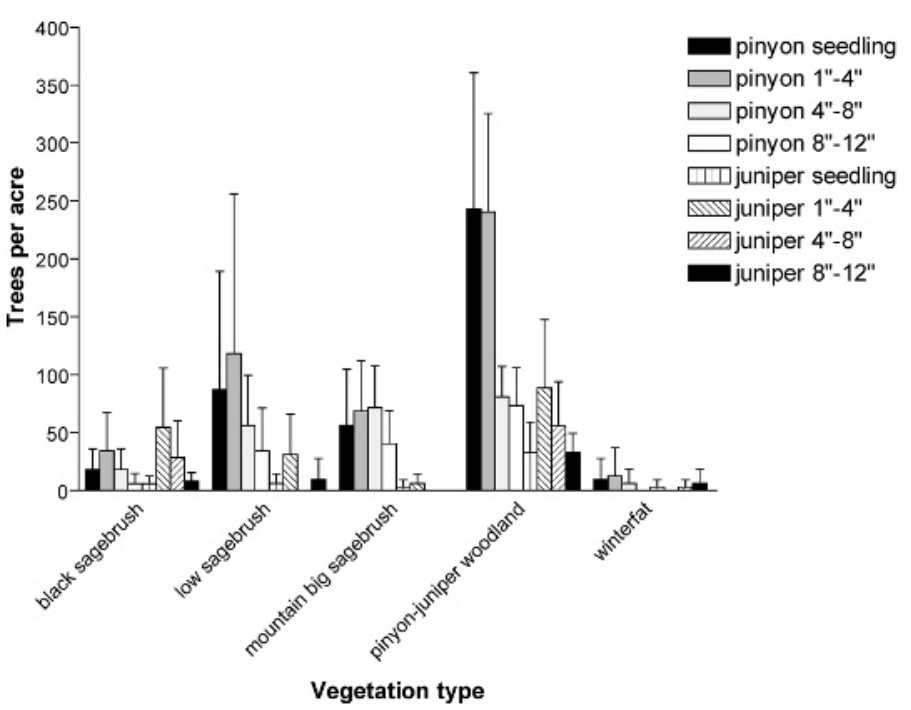

Figure 3. Pinyon and juniper density by plant size class in each of 6 major vegetation types from North Spring Valley field data.

acre; Fig. 3) and small adult $(240.3 \pm 85.2$ stems per acre; Fig. 3) size classes and most being pinyon. Of the juniper size classes, young adults were most abundant $(88.5 \pm 58.9$ stems per acre; Fig. 3).

Winterfat type had no trees and so is not represented in Figure 3. Wyoming big sagebrush type had few trees as well. The highest density of trees in the Wyoming big sagebrush type was the small pinyon size classes, which were $12.5 \pm 24.4$ stems per acre (Fig. 3). Low and mountain big sagebrush vegetation types, which occur at higher elevations, had more pinyon than juniper, and most of those were in the smaller size classes. No vegetation type had more large than small treesthe size class distribution was always skewed toward the smaller classes, suggesting that even in pinyon-juniper woodland, most of the trees are younger, indicating recent woody plant encroachment.

Ground cover was primarily bare ground, litter, and sometimes rock with low values for crust, plant, moss, and lichen (Fig. 4). The vegetation type with the highest cover of bare ground was winterfat type $(76.5 \pm 4.9 \%$; Fig. 4$)$. The type with the highest cover of biological crust was Wyoming big sagebrush type $(1.3 \pm 0.9 \%$; Fig. 4$)$.

One hundred and fourteen total species of vascular plants were identified in plots at the site through the point-intercept and 10-minute walk procedures. Mountain big sagebrush type was the most species rich, with 76 species. Black sagebrush type had 70 species, Wyoming big sagebrush type 41, low sagebrush type 57, pinyon-juniper woodland 43, and winterfat type 18 .

\section{Comparison with Reference Condition: Example from Mountain Big Sagebrush Type}

These data are meaningful only when compared with reference conditions; here we give an example of comparison with reference condition for 1 of our 6 vegetation types: mountain big sagebrush.

The distribution of vegetation classes in the landscape described by our estimated reference condition and our field data are shown in Table 1 and Figure 5. A chi-square test 


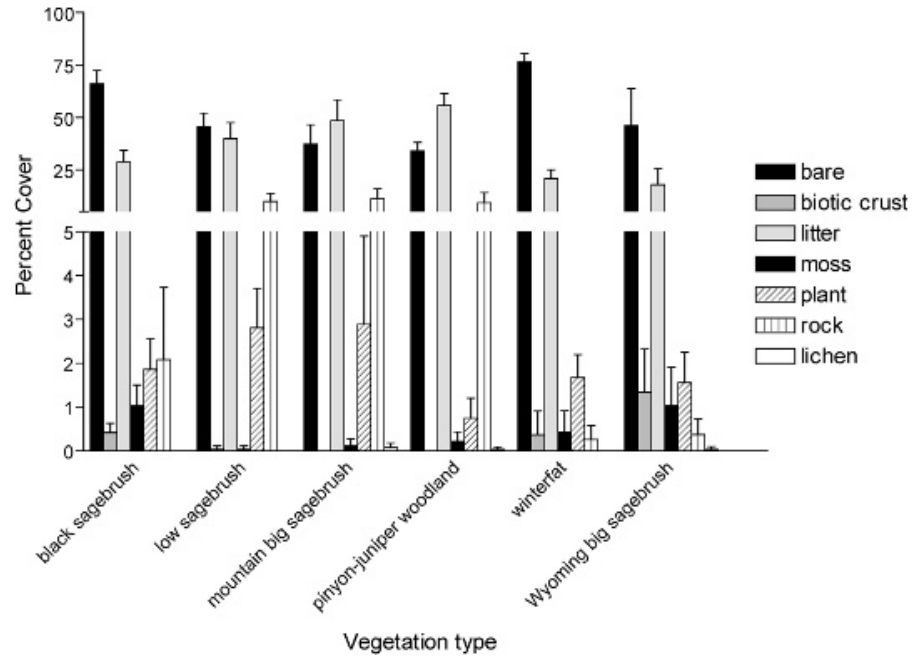

Figure 4. Percent ground cover within 6 major vegetation types from North Spring Valley field data.

showed that the expected distribution vegetation classes under the reference condition and the observed distribution from the field data are significantly different (chi-square $=302.7193$, $\mathrm{df}=4, P<0.001$ ). The earliest development classes (Table 1 ; class A [early development] and class B [mid-development open-shrubs]) were underrepresented in the landscape, and mountain big sagebrush moderately invaded by conifers (Table 1; class D [late-development, open-trees]) was too abundant by $+48.4 \%$ compared to the LANDFIRE historic range of variability. Classes most similar to the reference condition were mountain big sagebrush with the highest conifer cover (Table 1; class E [late-development closed-trees]; departure of $+1.9 \%$ ) and late-development mountain big sagebrush with perennial grasses (Table 1; class C [latedevelopment closed-shrubs]; departure of $+13 \%$; Figure 5).

\section{DISCUSSION}

Natural resources managers responsible for assessing and taking action to improve or maintain ecological condition of landscapes face 2 initial challenges: 1) to quantitatively assess the ecological condition of landscapes using limited financial resources and 2) to efficiently use data from these assessments to set management priorities. Overall, our approach has been to collect data using a statistically valid sampling design and power analysis and to evaluate these data based on a quantitative model developed by experts and users to guide management actions.

\section{Sampling Effort Required}

The time required to employ this method increases with 1) the distance of the area of interest from the base of operations, 2) the number of vegetation types to be assessed, and 3) the variability of the indicator (e.g., native herbaceous vegetative cover). The time requirement decreases with 1) the density of roads in the watershed, which decreases the average travel time to each sampling plot, and 2) the average value of the indicator (i.e., at higher values of herbaceous cover, herbaceous cover is

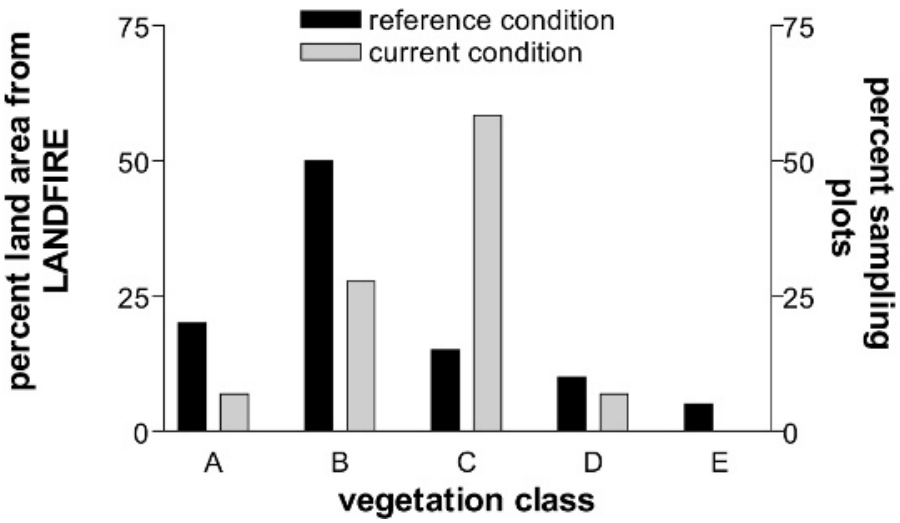

Figure 5. Percent of sampling plots in each vegetation class for current vegetation types and percent of land area in each vegetation class for the estimated reference condition in the mountain big sagebrush vegetation type.

easier to detect; therefore, fewer samples are needed to obtain the desired level of statistical power). North Spring Valley is approximately $100 \mathrm{~km}$ from Ely, Nevada, and is $48082 \mathrm{ha}$ and has approximately $523 \mathrm{~km}$ of road, so that the distance hiked to any sampling plot was generally $0.9 \mathrm{~km}$ or less. The average cost per hectare was $\$ 0.20$, including travel, data collection, and data entry (digital data recorders used in the field), but this cost does not include data management or analysis.

\section{Management Implications}

This assessment was performed to determine whether the current ecological condition of each potential vegetation type had sufficiently departed from the reference condition to justify management actions. Using the mountain big sagebrush example (Table 1), we identified that the classes dominated by conifer encroachment and the class with high sagebrush cover were overrepresented and that the earlier classes with greater relative herbaceous cover were underrepresented relative to reference conditions.

The reasons for the departure from reference conditions are not known specifically for North Spring Valley, as spatial information in fire history goes back only to the mid-1980s, and spatial information on grazing history is also very limited. However, it is likely that in this region, as in much of the Great Basin, extensive grazing took place between 1880 and 1910 (Young and Sparks 1985). Grazing removed much of the herbaceous component from shrubland systems, which reduced the continuous herbaceous fuels that would have allowed natural fires to spread. Reduced fire frequency is the main casual factor linked to the expansion of juniper (Evans and Young 1987). Prior to European settlement, fire was an important factor mediating the distribution of successional stages in fire-dependent vegetation types, but grazing, fire suppression, and the creation of firebreaks along roads dramatically decreased the number and extent of wildfires (Burkhardt and Tisdale 1976), which has allowed vegetation types to progress further along successional axes, as we see here.

Assuming that the LANDFIRE historic range of variability is the desired range of future conditions, land managers might 
choose to increase the extent of early (class A [early development]) and mid-development (class B [mid-development open-shrubs]) classes of vegetation but decrease the extent of all other classes.

The extent of early and mid-development classes can be increased only at the expense of late-development mountain big sagebrush (class C [late-development closed-shrubs]) and mountain big sagebrush with moderate conifer encroachment (class D [late-development open-trees]). Because class D contains up to $30 \%$ herbaceous cover, we recommend prescribed burning with replacement fire on approximately $20 \%$ of the landscape in class D to achieve approximately $20 \%$ of the landscape in class A, which should progress into class B after approximately 12 years. This strategy should allow the site to meet the $6 \%-25 \%$ prescription for the percent of the landscape in class B. Burns should be small (e.g., 100 ha) and patchy and would be expected to create early development vegetation classes dispersed in the landscape. Native seeding is not required as a result of any restoration actions because understory grasses and the seed bank are usually sufficiently abundant in this potential vegetation type. Once an area is burned, livestock grazing should be prevented for a few years (Monsen et al. 2004).

The mid-development vegetation class (Table 1, class B) is the hardest to recruit because, although different treatment methods of varying cost can be used, the least expensive method (prescribed fire) is also the most difficult to control to reach management objectives. For example, mechanical thinning and patchy, mixed-severity prescribed burning of vegetation classes C (late-development closed-shrubs) and D (latedevelopment open-trees) could be used (Bates et al. 2000; Brockway et al. 2002). If mixed-severity prescribed burning is used to thin woody cover, then it should be applied to class D because the lower fuel loads will ensure a mosaic burn; indeed, replacement fire naturally dominates mountain big sagebrush because of continuous fuels. Although mixed-severity prescribed burning can be applied to class $\mathrm{C}$ to thin sagebrush cover within a range of $6 \%-25 \%$, fuel specialists may choose mechanical thinning to reach this objective because they may find it safer and more predictable, although it is more expensive. It should also be noted that managers can thin shrub and conifer cover by herbicide application.

We described here one of many alternative approaches to restore the historic range of variability of mountain big sagebrush in 1 watershed. Land managers may choose a very different approach, perhaps even a passive one, such as implementing a wildfire use plan to safely take advantage of the beneficial effects of natural ignitions. Not described here is the spatial layout of restoration actions to restore the historic range of variability. The spatial design of restoration actions at the landscape level is not a trivial task if conflicting goals (e.g., Hemstrom et al. 2001), such as reintroducing fire regimes and managing the wildland-urban interface, are present.

One important kind of information that is missing from our method and analysis is a complete spatial picture of the ecological condition of this landscape. Sampling plots are georeferenced and provide information about departure indices at a point in time. Because we used power analysis, we are confident (at the alpha $=0.2$ level) that our sampling plots have captured the variation across the landscape. However, we do not know the spatial arrangement of that variation, which should more realistically be viewed as a mosaic of successional classes within each vegetation type. This gap in our understanding of the landscape could be filled in the future by integrating remote sensing with our field data methods.

\section{Future Work: Combination of Field and Remote Sensing Data}

The next step in developing a landscape-scale monitoring program will be the integration of remote sensing with field data. Some authors advocate remote sensing as the only costeffective way to inventory landscapes (e.g., Booth and Tueller 2003). The rationales for this idea are that landscape-level field sampling is prohibitive and that remote sensing will provide data necessary for management decisions. The actual cost of field sampling, however, depends on travel time to sampling sites, which, in turn, depends on the accessibility of the landscape being monitored. In many cases, rangeland sites are highly accessible because of their valley-bottom position and the networks of roads created for livestock water developments. Moreover, remote sensing requires field validation (Wisdom et al. 2005), even at regional scales.

One problem with using only remotely sensed data is that indicators of interest may not always be measurable. Many authors advocate using bare ground as the primary indicator (e.g., DeSoyza et al. 2000; Booth and Tueller 2003), but this may not be sufficient in many management systems, particularly when management decisions require other information. For example, one threshold critical to managers in the Great Basin is the transition from a class comprised of shrubs with native herbaceous understory to a class with shrubs and an exotic herbaceous understory. These classes cannot be readily distinguished using available remote sensing technologies because the spectral signature of exotic annual grasses cannot be easily distinguished from that of native perennial grasses (Menakis et al. 2003) and, more important, because of the difficulty of detecting subcanopy cover. Additionally, remote sensing is generally not capable of identifying herbaceous species, an issue at the heart of some management issues, for example, when managers need to determine whether the herbaceous understory has sufficient native forb cover to support the diet of Greater Sage-grouse (Centrocerus urophasianus).

However, remote sensing has become a necessary tool for timely assessment of large landscapes, and it will provide data for the entire landscape rather than just isolated portions. Our sampling method was designed to complement and support current and future remote sensing analyses by fitting a plot to approximately match a LandSat pixel. This will allow future remote sensing efforts to compare $30-\mathrm{m}$ pixel values for vegetation cover with our field vegetation cover data. Although our plots are unlikely to have fallen in the center of a pixel, this design will allow for more efficient weighting of central and surrounding pixels. This will allow current sampling efforts to create a database against which remote sensing imagery can be calibrated.

The challenge in combining remote sensing and field data will be to determine which variables can be more efficiently mapped using remote sensing versus field sampling. Tree cover and density is measurable with digital orthophotoquads, high- 
resolution imagery, low-flying aircraft imagery, or even lowresolution LandSat7 imagery if tree cover is sufficiently high, and shrub cover can be similarly measured with some methods.

In future efforts, we will strive to use remote sensing to 1) prioritize areas for field data sampling and 2) measure indicators that can efficiently and accurately be measured from imagery to 3) compare current conditions with potential conditions, estimated as done previously, from soils maps and vegetation models. In this way, we will be able to combine field sampling with remote sensing to more efficiently assess the condition of large landscapes.

\section{ACKNOWLEDGMENTS}

Field assistance was provided by Rhoda Godfrey, Sydney Van Ausdal, and Alan, Sean, and Karen de Queiroz. Botanical assistance was provided by Arnold Tiehm. Helpful comments on the manuscript were provided by David Briske, Jeff Herrick, Don Major, and Alan de Queiroz.

\section{LITERATURE CITED}

Anderson, J. E., And R. S. Inouye. 2001. Landscape-scale changes in plant species abundance and biodiversity of a sagebrush steppe over 45 years. Ecological Monographs 71(4):531-556.

Bastin, G. N., V. H. Chewings, J. Ludwig, R. Eager, A. Liedloff, and R. Karfs. 2002. Monitoring landscape function with remotely-sensed imagery. Range Management Newsletter 2(1):7-11.

Bates, J. D., R. F. Mlller, and T. J. Svejcar. 2000. Understory dynamics in cut and uncut western juniper woodlands. Journal of Range Management 53:119-126.

Boотн, D. T., and P. T. Tueller. 2003. Rangeland monitoring using remote sensing. Arid Land Research and Management 17(4):455-467.

Brockway, D. G., R. G. Gatewood, and R. B. Paris. 2002. Restoring grassland savannas from degraded pinyon-juniper woodlands: effects of mechanical overstory reduction and slash treatment alternatives. Journal of Environmental Management 64:179-197.

[BLM] Bureau of Land Management. 1996. Sampling vegetation attributes: Interagency technical reference. Denver, C0: BLM National Applied Resource Sciences Center. BLM/RS/ST-96/002-1730. 164 p.

Burkhardt, J. W., and E. W. Tisdale. 1976. Causes of juniper invasion in southern Idaho. Ecology 57:472-484.

Comer, P., D. Faber-Langendoen, R. Evans, S. Gawler, C. Josse, G. Kittel, S. Menard, M. Pyne, M. Reid, K. Schulz, K. Snow, and J. Teague. 2003. Ecological systems of the United States: A working classification of U.S. terrestrial systems. Arlington, VA: NatureServe. $75 \mathrm{p}$.

Cronquist, A., A. H. Holmgren, N. H. Holmgren, J. L. Reveal, and P. K. Holmgren. 1972. Intermountain flora: Vascular plants of the Intermountain West. New York, NY: New York Botanical Garden. 270 p.

Desoyza, A. G., W. G. Whitford, S. J. Turner, J. W. Van Zee, and A. R. Johnson. 2000. Assessing and monitoring the health of western rangeland watersheds. Environmental Monitoring and Assessment 64:153-166.

Elzinga, C. L., D. W. Salzer, And J. W. Willoughby. 1998. Measuring and monitoring plant populations. Bureau of Land Management Technical Reference 1730-1.

Evans, R. A., And J. A. Young. 1987. Control, plant succession, and revegetation in western juniper woodlands. In: R. L. Everett [ED.]. Proceedings: Pinyon-juniper conference. USDA Forest Service Gen. Tech. Rep. INT-215. p 301-304.

Fairweather, P. G. 1991. Statistical power and design requirements for environmental monitoring. Australian Journal of Marine and Freshwater Research 42:555-567.

Gram, W. K., V. L. Sork, R. J. Marquis, R. B. Renken, R. L. Clawson, J. Faaborg, D. K. Fantz, J. Le CorfF, J. Lill, and P. A. Porneluzi. 2001. Evaluating the effects of ecosystem management: a case study in a Missouri Ozark forest. Ecological Applications 11(6):1667-1679.
Heinz Center. 2002. The state of the nation's ecosystems: Measuring the lands, waters and living resources of the United States. New York, NY: Cambridge University Press.

Hemstrom, M. A., J. J. Korol, and W. J. Hann. 2001. Trends in terrestrial plant communities and landscape health indicate the effects of alternative management strategies in the interior Columbia river basin. Forest Ecology and Management 153:105-125.

Herrick, J. E., J. W. Van Zee, K. M. Havstad, L. M. Burkett, and W. G. Whitford. 2005. Monitoring manual for grassland, shrubland, and savanna ecosystems. Volume II: Design, supplementary methods, and interpretation. Tucson, AZ: University of Arizona Press. 200 p.

Holthausen, R., R. L. Czaplewski, D. Delorenzo, G. Hayward, W. B. Kessler, P. Manley, K. S. McKelvey, D. S. Powell, L. F. Ruggiero, M. K. Schwartz, B. Van Horne, and C. D. VoJTA. 2005. Strategies for monitoring terrestrial animals and habitats. Gen. Tech. Rep. RMRS-GTR-161. Fort Collins, C0: US Department of Agriculture, Forest Service, Rocky Mountain Research Station. 34 p.

Holthausen, R., R. Czaplewski, D. Delorenzo, G. Hayward, W. Kessler, P. N. Manley, K. McKelvey, D. S. Powell, L. Ruggiero, M. Schwartz, B. Van Horne, and C. Voutta. 2005. Strategies for monitoring terrestrial animals and habitats. Gen. Tech. Rep. RMRS-GTR-161. Fort Collins, C0: US Department of Agriculture, Forest Service, Rocky Mountain Research Station. 34 p.

Malkinson, D., R. Kadmon, and D. Cohen. 2003. Pattern analysis in successional communities-an approach for studying shifts in ecological interactions. Journal of Vegetation Science 14(2):213-222.

Menakis, J. P., D. Osborne, And M. Miller. 2003. Mapping the cheatgrass-caused departure from historical natural fire regimes in the Great Basin, USA. Denver, CO: USDA Forest Service Proceedings RMRS-P-29. 698 p.

Monsen, S. B., R. Stevens, and N. L. Shaw [Comps]. 2004. Restoring western ranges and wildlands. Gen. Tech. Rep. RMRS-GTR-136-vol-1. Fort Collins, CO: US Department of Agriculture, Forest Service, Rocky Mountain Research Station. $294 \mathrm{p}$.

Nickerson, D. M., and A. Brunell. 1998. Power analysis for detecting trends in the presence of concomitant variables. Ecology 79(4):1442-1447.

Oba, G., E. Post, P. O. Syvertsen, and N. C. Stenseth. 2000. Bush cover and range condition assessments in relation to landscape and grazing in southern Ethiopia. Landscape Ecology 15(6):535-546.

PyKE, D. A., AND J. E. HerRICK. 2004. Transitions in rangeland evaluations: a review of the major transitions in rangeland evaluations during the last 25 years and speculation about future evaluations. Rangelands 25(6):22-30.

SteIDL, R. J., AND L. Thomas. 2000. Using statistical power analysis to improve design of ecological experiments. In: S. Scheiner and J. Gurevitch [EDS.]. Design and analysis of ecological experiments. 2nd ed. New York, NY: Chapman \& Hall.

Stephenson, N. L. 1999. Reference Conditions for giant sequoia forest restoration: structure, process, and precision. Ecological Applications 9(4): 1253-1265.

Stringham, T. K., W. C. Krueger, and P. L. Shaver. 2003. State and transition modeling: an ecological process approach. Journal of Range Management 56(2):106-113.

Swanson, F. J., AND J. F. Franklin. 1992. New forestry principles from ecosystem analysis of Pacific Northwest forests. Ecological Applications 2:262-274.

Thompson, W. L. [ed.]. 2004. Sampling rare or elusive species: Concepts, designs, and techniques for estimating population parameters. Washington, DC: Island Press. $429 \mathrm{p}$.

ThuRow, T. L. 1991. Hydrology and erosion. In: R. Heitschmidt and J. Stuth Portland [EDS.]. Grazing management: An ecological perspective. Portland, OR: Timberline Press. 259 p.

[USDA, nRCS] US Department of Agriculture, Natural Resources Conservation ServicE. 1997. National range and pasture handbook. Washington, DC: USDA, NRCS. Grazing Lands Technology Institute 190-vi-NRPH. 571 p.

Wisdom, M. J., M. M. Rowland, and L. H. SuRing [eds.]. 2005. Habitat threats in the sagebrush ecosystem: methods of regional assessment and applications in the Great Basin. Lawrence, KS: Alliance Communication Group. 301 p.

Young, J. A., and B. A. Sparks. 1985. Cattle in the Cold Desert. Reno, NV: University of Nevada Press. 